\title{
Corporate Ownership Structure and the Informativeness of Earnings
}

\author{
Gillian H.H. Yeo, Patricia M.S. Tan, Kim Wai Ho and \\ Sheng-Syan Ghen*
}

\section{INTRODUCTION}

Management typically has discretion over the recognition of accruals and this discretion can be used by management to signal their private information or to opportunistically manipulate earnings. To the extent that management uses their discretion to manipulate accruals, earnings will become less informative. Also, managers in their choice of accepted accounting procedures could choose to reflect the economics underlying the transactions or select accounting techniques to reflect accounting numbers for personal benefit. This will in turn, influence the informativeness of earnings. Prior studies in the United States have examined the relationship between management ownership structure and earnings management. For example, ${ }^{1}$ Warfield, Wild and Wild (1995) has shown that managerial ownership is positively associated with earnings explanatory power for returns and inversely related to the magnitude of discretionary accounting accruals. When

\footnotetext{
* The first three authors are from Nanyang Technological University. The fourth author is from Yuan Ze University. They wish to thank an anonymous referee, Cheng-few Lee, Anthony Catanach, Grace Pownall, Carol Frost and seminar participants at the 1998 American Accounting Association Annual Meeting, 1998 Accounting Association of Australia and New Zealand Annual Meeting and Sixth Conference on Pacific Basin Business, Economics and Finance. (Paper received August 2000, revised and accepted July 2001)
}

Address for correspondence: Gillian H.H. Yeo, Nanyang Business School, Nanyang Technological University, Singapore 639798.

e-mail: ahhyeo@ntu.edu.sg 
managerial ownership is low, the increased demand for accounting-based constraints motivate managers to strategically choose accounting policies and determine accounting accruals in an attempt to mitigate the accounting-based contractual restrictions. Thus, the accounting choice is not necessarily the most relevant in conveying the economic substance of underlying transactions.

This study further extends previous studies by empirically examining how managerial ownership and external unrelated block holdings affect the informativeness of earnings for companies listed on the Stock Exchange of Singapore. This study contributes to the existing literature in the following ways. First, the findings of Warfield et al. (1995) that the informativeness of earnings improves as managerial ownership increases is based on Jensen and Meckling's (1976) agency theory. Managers of low managerial ownership firms have greater incentives to manage accounting numbers to relieve or relax the behavioral constraints imposed in accounting-based contracts used to discourage managers from non-value-maximizing actions. However, Morck, Shleifer and Vishny (1988) show that high ownership by management implies sufficient voting power to guarantee future employment and as a consequence, becomes ineffective in aligning managers to take value-maximizing decisions. The corporate ownership structure of Singapore listed companies comprises mainly companies that originally started off as family-owned businesses as well as government state-owned enterprises. Due to family owned businesses, the management ownership numbers of Singapore listed firms are much higher than those of US companies. Hence, this study provides an opportunity to examine if there could potentially be a non-linear relationship between management ownership and the informativeness of earnings.

Interestingly, in contrast to the results of Warfield et al. (1995), a study by Rajgopal, Venkatachalam and Jiambalvo (1999) that examines the relationship between institutional ownership and earnings management shows no significant relation between discretionary accruals and managerial ownership. A plausible explanation suggested is that while Rajgopal et al. (1999) use the modified Jones (1991) model in measuring non-discretionary accruals, Warfield et al. (1995) use the five-year average of prior 
period accruals. Our study further provides an opportunity to test the conflicting predictions between management ownership and discretionary accruals by using the modified Jones (1991) model and provides additional evidence to examine if a potential nonlinear relationship exists between income-increasing discretionary accruals and managerial ownership that is consistent with the analysis for the informativeness of earnings.

Second, there is also considerable evidence that large shareholders address the agency problem in that they have a general interest in profit maximization and enough control over the assets of the firm to have their interests respected (Shleifer and Vishny, 1986). Substantial external unrelated shareholders have the incentives to collect information and monitor management and enough voting control to oust management through takeovers. Dechow, Sloan and Sweeney (1996) find that firms subject to SEC's enforcement actions for earnings manipulation are more likely to have boards of directors dominated by management and less likely to have outside block holders. The existence of substantial outside block holders thus leads to closer monitoring or scrutiny of management and this implies lesser opportunity for accruals management or earnings manipulation. Rajgopal et al. (1999) also shows that the absolute value of discretionary accruals decline with institutional ownership since institutional owners are better informed than individual investors and this reduces the perceived benefit of managing accruals. It is common for companies in Singapore to have concentrated shareholdings or block holdings and these can include both related and unrelated parties (individuals, corporations and government). Though pyramid holdings exist in Singapore companies, the presence of cross-holdings is restricted due to prohibition by the Singapore Companies Act in the case of holding-subsidiary relationships. It is expected that concentrated shareholdings by related parties through crossholdings or pyramid holdings are less effective for monitoring purposes. Hence it is interesting to explore the monitoring effects of the block holding ownership structure of Singapore firms on the informativeness of earnings.

Finally, the findings of this study provide valuable insights to international investors and fund managers in their portfolio diversification strategies around the world. The findings of the 
effects of corporate governance on the informativeness of earnings are important information to investors and fund managers in their selection of Singapore companies to invest in. In the recent 1999 Global Competitiveness Report conducted by the Geneva-based World Economic Forum (WEF), Singapore maintained top position as the world's most competitive economy for a fourth consecutive year since 1996 despite the currency turmoil that has hit the Asian region. Singapore's GDP per capita projected by WEF for the period 2000-2008 would be $5.02 \%$, the fastest growing economy in the world (The Straits Times, July 14, 1999). Singapore is thus an important investment center for international fund managers and this study aims to add to the understanding of the corporate ownership structure of Singapore companies as well as its effects on the informativeness of earnings.

The findings are likely to be relevant for investment decisions in continental Europe and other countries with large block holders. In fact, a study by La Porta et al. (1999) on ownership structures in 27 wealthy countries concludes that the widely held corporation is far from universal. Instead, most firms have controlling shareholders. Another survey by Becht and Roell (1999) show that in much of continental Europe, there are generally large block holders with some degree of control over management. The existence of substantial external unrelated shareholders is likely to mitigate the agency conflict between managers and owners and potentially affect the relationship between managerial ownership and the informativeness of earnings.

The results of our study show that the informativeness of earnings does not always increase with managerial ownership, in contrast with Warfield et al. (1995). At low levels of management ownership, the informativeness of earnings (level of incomeincreasing discretionary accruals) has a positive (negative) relationship with management ownership. However, at higher levels of management ownership, the relationship reverses suggesting that the entrenchment effect might have set in. Also, the findings show that external unrelated block holdings play a significant monitoring role. The presence of pyramid holdings and minimal cross-holdings do not reduce the effects of monitoring by the external unrelated blockholdings. When external unrelated blockholding is high, regardless of the level 
of managerial ownership, the results indicate lesser opportunities for earnings management.

The paper proceeds as follows. Section 2 describes the corporate ownership structure of Singapore companies. Research hypotheses are developed in Section 3 and model and variable definitions are given in Section 4. The data used is described in Section 5 and empirical results are reported in Section 6. Concluding remarks are summarized in the final section.

\section{CORPORATE OWNERSHIP STRUCTURE OF SINGAPORE COMPANIES}

The corporate ownership structure of Singapore listed companies comprises two main types. The first type comprises companies which originally started off as private Chinese familyowned businesses conducting the bulk of primary commodity trade (e.g. rubber, pepper), manufacturing and financial and business services. As such the controlling owners of these companies which started off as family businesses are mainly the founders or their offspring.

The second type are companies which originally started off as government state-owned enterprises. The means by which Singapore achieved its rapid post 1966 manufacturing development was through a set of entrepreneurs in the form of multinational corporations (MNCs) and the government itself became an entrepreneur in a big way. Strong government intervention was required for injection into Singapore's economy of multinationals and public enterprises. A number of foreign multinational enterprises especially in the electrical and electronics areas set up factories and offices in Singapore. A number of public or state-owned enterprises were set up by the government. Singapore's state-owned enterprises remained notable for efficient and effective management and the vast majority of state-owned enterprises were run at profit. To counter complaints of the 'crowding out' of local entrepreneurs, a privatization policy was announced in March 1985 to reduce the importance of the state-owned enterprises sector. A divestment program was pursued for a number of companies, but nevertheless, the government still retained substantial shareholdings especially for the more strategic industries. 
Thus for Singapore companies, the high management ownership companies are likely to be those which started off as family-owned businesses. It is common for companies to have large shareholdings and these are defined as concentrated shareholdings greater than five percent held by private individuals, companies or the government. The Stock Exchange of Singapore regulations require companies to disclose concentrated shareholdings greater than five percent.

These concentrated shareholdings can include both related and unrelated parties (individuals, corporations and government). Companies that started off as family-owned businesses are more likely to have related party shareholdings. Companies that started off as government state-owned enterprises and were subsequently privatized have shareholdings held by the government and other unrelated parties. Claessens, Djankov and Lang (2000) and La Porta et al. (1999) indicate that in all East Asian countries, control is enhanced through pyramid structures and cross-holdings among firms. As defined in La Porta et. al. (1999) and Claessens et. al. (2000), cross-holdings exist if the firm both has a controlling shareholder and owns shares in its controlling shareholder or in a firm that belongs to her chain of control. Section 21 of the Singapore Companies Act prohibits cross-holdings in the case of a holding-subsidiary ${ }^{2}$ relationship. As such the presence of cross-holdings in Singapore companies is restricted. Pyramid holdings exist if the controlling shareholder exercises control through at least one publicly traded company. Pyramid holdings are present in Singapore companies.

\section{RESEARCH HYPOTHESES}

Theory predicts that low managerial ownership implies poor alignment of interests between management and shareholders (Jensen and Meckling, 1976) and managers have incentives to pursue non-value-maximizing behavior. This gives rise to a higher demand for accounting-based constraints to mitigate managers' opportunistic behavior. To relieve or relax these constraints, managers of low managerial ownership firms have greater incentives to manage accounting numbers. They choose 
accounting techniques conditional on contractual constraints, and not necessarily to reflect the economics of the underlying transaction. Also, in order to reduce the potential impact of the constraints, greater accrual adjustments are expected the lower the managerial ownership. Thus, the informativeness of earnings is predicted to be positively related to managerial ownership, and the magnitude of discretionary accounting accruals, inversely related to managerial ownership. The findings in Warfield et al. (1995) show that managerial ownership is positively associated with earnings' explanatory power for returns and inversely related to the magnitude of accounting accrual adjustments.

On the other hand, as managerial ownership increases, the managerial labour market and the market for corporate control become less effective in aligning managers to take valuemaximizing decisions. This is because high ownership by management implies sufficient voting power to guarantee future employment (Morck, Shleifer and Vishny, 1988). As shown by Morck et al. (1988), entrenched managers have incentives to pursue self-interest non-value maximizing actions at the expense of shareholder wealth. These non-value maximizing actions may include earnings management with direct wealth effects for management (e.g. increasing earnings to increase bonuses, etc.). The incentives for non-value maximizing actions are stronger when there is less monitoring by external unrelated block holders. Dechow et al. (1996) find that an important motivation for earnings manipulation is the desire to attract external financing at low cost. They also show that firms manipulating earnings are less likely to have an outside block holder. There is evidence in the US literature that earnings management has negative effects on share prices. Teoh and Wong (1998) show that firms with income-increasing abnormal accruals in the year of seasoned equity offer have significant subsequent stock underperformance. Hence, the entrenchment effect as indicated by Morck et al. (1988) potentially confounds the agency theory predictions. As managerial ownership increases, earnings management may increase.

Due to the presence of family-owned businesses, the mean (median) management ownership numbers in Singapore companies are high compared to the US. The mean (median) management ownership numbers in Singapore companies are 
$27.1 \%$ (24.7\%), compared to the $16.4 \%$ (6.4\%) for US companies in Warfield et al. (1995). Our study addresses these conflicting predictions by examining the effects of agency theory and entrenchment on the relationship between the informativeness of earnings and discretionary accounting accruals with managerial ownership. We also use income-increasing discretionary accruals to test for the effects of agency versus entrenchment. The use of income-increasing discretionary accruals provides a direct test of whether aggressive earnings management to raise reported earnings exists as a result of the entrenchment effect or whether the agency theory predictions hold and earnings management is reduced as managerial ownership increases.

There is also considerable evidence in the US that large shareholders play an active role in the corporate governance process (Shleifer and Vishny, 1986). Large shareholders address the agency problem in that they have a general interest in profit maximization and enough control over the assets of the firm to have their interests respected. Substantial external unrelated shareholders have the incentives to collect information and monitor management and enough voting control to oust management through takeovers. There is considerable evidence that substantial external unrelated shareholders play an active role in exercising corporate governance. For example, Kaplan and Minton (1994) and Kang and Shivdasani (1995) show that firms with large shareholders are more likely to replace managers in response to poor performance than firms without them. Dechow, Sloan and Sweeney (1996) find that firms subject to SEC's enforcement actions for earnings manipulation are more likely to have a board of directors dominated by management and less likely to have external unrelated block holders. Thus the existence of substantial external unrelated block holders leads to closer monitoring of management and this implies less opportunity for accruals management or earnings manipulation.

The monitoring by substantial external unrelated shareholdings is similar to the effect of regulation and institutional ownership. It attenuates managers' non-value maximizing behavior, and as such, the opportunities for managers to capitalize on the latitude in accounting techniques is reduced. The results of Warfield et al. (1995) show that managerial 
ownership is less important in affecting the informativeness of earnings for regulated corporations, suggesting regulation monitors managers' accounting choice. The study by Rajgopal et al. (1999) shows a strong negative relation between the absolute value of discretionary accruals and institutional ownership. This is consistent with the view that institutional owners are better informed, thus the perceived benefits of managing accruals are reduced.

As mentioned in Section 2, companies in Singapore have concentrated shareholdings that can include both related and unrelated parties (individuals, corporations and government). It is expected that concentrated shareholdings by related parties through cross-holdings or pyramid holdings are less effective for monitoring purposes. Cross-holdings are restricted in Singapore due to the prohibition by the Singapore Companies Act in the case of holding-subsidiary relationships. As such, in this study, we excluded all related parties when we collected the sample of concentrated shareholdings for the companies. Pyramid holdings may be included and any cross-holdings that may be included are restricted to a minimum (we explicitly excluded all identifiable related parties). With this sample of concentrated shareholdings, we test the effectiveness of blockholder monitoring on the informativeness of earnings and discretionary accruals including income-increasing accruals.

There are other considerations affecting managers' incentives in the choice of accounting techniques and the level of discretionary accruals, and the reporting of the accounting numbers. Following Warfield et al. (1995), we introduce six additional factors in the empirical analysis to enhance the reliability of the inferences from the analysis. They are namely, firm size, leverage, risk, growth opportunities, earnings variability and earnings persistence. Managers of large politically sensitive firms are more inclined to engage in earnings management to reduce political costs, and high-risk firms have greater incentives to do so. Managers of firms with high agency costs of debt are more likely to make strategic accounting choices to relieve potential constraints on their behavior. ${ }^{3}$ The other factors, growth opportunities, earnings variability and persistence are related to the firm valuation literature. High growth opportunities and high persistence would lead to larger share 
price reaction, while managers of firms with high earnings variability would tend to smooth earnings to maximize firm value.

\section{MODEL AND VARIABLE DEFINITIONS}

The empirical analysis is conducted in the following stages. The first stage is on the analysis of the information content of earnings conditional on management ownership and external unrelated block holdings. As in Warfield et al. (1995), the additional factors affecting managers' incentives in earnings management considered in these tests are firm size, leverage, systematic risk, earnings variability, growth opportunities and earnings persistence. The following pooled cross-sectional time series model is estimated:

$$
\begin{aligned}
R_{i t}= & a_{0}+a_{1} E_{i t} / P_{i t-1}+a_{2} \operatorname{MGOWN}_{i} E_{i t} / P_{i t-1}+a_{3} \mathrm{BLOCK}_{i} E_{i t} / P_{i t-1} \\
& +a_{4} \mathrm{SIZE}_{i} E_{i t} / P_{i t-1}+a_{5} \mathrm{DEBT}_{i} E_{i t} / P_{i t-1}+a_{6} \mathrm{RISK}_{i} E_{i t} / P_{i t-1} \\
& +a_{7} \mathrm{VAR}_{i} E_{i t}+a_{8} \mathrm{GROWTH}_{i} E_{i t} / P_{i t-1}+a_{9} \mathrm{PERS}_{i} E_{i t} / P_{i t-1} \\
& +u_{i t}
\end{aligned}
$$

$R_{i t}$ is the 12-months stock returns of firm $i$ in period $t$, starting nine months prior to fiscal year-end through three months after fiscal year-end. ${ }^{4} E_{i t}$ is earnings per share of firm $i$ in period $t$. MGOWN $_{i}$ is the percentage of outstanding equity shares owned by directors. $\mathrm{BLOCK}_{i}$ is the percentage of external unrelated block holding. SIZE $_{i}$ is the natural logarithm of market value of equity. $\mathrm{DEBT}_{i}$ is debt to total assets ratio. $\mathrm{RISK}_{i}$ is the systematic risk (market model beta). $\mathrm{VAR}_{i}$ is the coefficient of variation of earnings for the previous eight years. GROWTH ${ }_{i}$ is market to book ratio. $\mathrm{PERS}_{i}$ is the persistence of earnings as measured by the first order autocorrelation in earnings for the previous eight years. Due to the lack of independence in pooled observations (Teets and Wasley, 1996), we estimated equation (1) again by sub-classifying the sample by years.

The second stage investigates the relation between external unrelated block holdings and the absolute value of discretionary accruals. The discretionary accruals are estimated using the modified Jones (1991) model. The following regression is estimated for every firm: 


$$
\begin{aligned}
\mathrm{ACC}_{t} / \mathrm{TA}_{t-1}= & \alpha_{1}\left[1 / \mathrm{TA}_{t-1}\right]+\alpha_{2}\left[\left(\Delta \mathrm{SAL}_{t}-\Delta \mathrm{REC}_{t}\right) / \mathrm{TA}_{t-1}\right] \\
& +\alpha_{3}\left[\mathrm{PPE}_{t} / \mathrm{TA}_{t-1}\right]+\varphi_{t}
\end{aligned}
$$

where ACC is aggregate accruals, TA is total assets, $\triangle \mathrm{SAL}$ is the change in net sales, $\triangle$ REC is the change in net receivable, and PPE is gross property, plant and equipment. Aggregate accruals are defined as in Dechow et al. (1995). The residuals $\left(\varphi_{t}\right)$ obtained from equation (2) represent the firm-specific discretionary accruals.

A pooled cross-sectional time series regression model is used to investigate the joint interaction of management ownership, external unrelated block holdings and income-increasing discretionary accruals (DACINC). The analysis is also repeated with the absolute value of discretionary accruals.

$$
\begin{aligned}
\text { DACINC }_{i t}= & b_{0}+b_{1} \mathrm{MGOWN}_{i t}+b_{2} \mathrm{BLOCK}_{i t}+b_{3} \mathrm{SIZE}_{i t} \\
& +b_{4} \mathrm{DEBT}_{i t}+b_{5} \mathrm{RISK}_{i t}+b_{6} \mathrm{VAR}_{i t}+b_{7} \mathrm{GROWTH}_{i t} \\
& +b_{8} \mathrm{PERS}_{i t}+u_{i t} .
\end{aligned}
$$

The explanatory variables are defined as previously. We also estimated equation (3) again by sub-classifying the sample by years.

\section{DATA AND EMPIRICAL RESULTS}

Stock price and financial statement data are obtained from the Stock Exchange of Singapore. Our data span the years 1990 through 1992. All firms listed on the Stock Exchange are used for which accounting and stock returns are available for the years 1990 to 1992. The resulting sample consists of 490 firm-year observations: $86 \%$ of the firms are in the industrial and commercial sector, $9 \%$ in the finance sector and $5 \%$ in the property sector. ${ }^{5}$

Table 1 presents tests aimed at measuring the relationship between the informativeness of earnings and levels of managerial ownership. For the entire sample, the correlation between earnings and returns is positive (0.32) and significantly greater than zero at the 0.01 level, similar to prior research. More interesting, however, is the pattern exhibited in the magnitude of the correlation between earnings and returns across managerial 


\section{Table 1}

Relation Between Earnings and Returns Dependent on the Level of Management Ownership

\begin{tabular}{lccc}
\hline $\begin{array}{l}\text { Management } \\
\text { Ownership Percent }\end{array}$ & $\begin{array}{c}\text { Number of Firm-period } \\
\text { Observations }\end{array}$ & $\begin{array}{c}\text { Correlation between } \\
\text { Earnings and Returns }\end{array}$ & $\begin{array}{c}\text { Earnings } \\
\text { Coefficient }\end{array}$ \\
\hline $0-100$ & 490 & 0.320 & 0.671 \\
$0-0.1$ & 121 & 0.390 & 0.766 \\
$0.1-25$ & 126 & 0.460 & 0.879 \\
$25-50$ & 107 & 0.243 & 0.539 \\
$>50$ & 136 & 0.200 & 0.423 \\
\hline
\end{tabular}

Notes:

All correlations (Pearson) between annual accounting earnings per share and stock returns, and earnings coefficients from regression of stock returns on accounting earnings per share are significant at the 0.01 level. Stock returns are measured for the 12-months period, starting nine months prior to fiscal year-end through three months after fiscal year-end. Earnings per share are scaled by share price at beginning of period and management ownership is the percentage of outstanding equity shares owned by directors. The sample consists of 490 firm-year observations drawn from the 1990-1992 calendar years.

ownership levels. Specifically, the correlation increases from 0.39 for the 0-0.1 percent ownership group to 0.46 for the $0.1-25$ percent group. However, it declines to $0.243(0.2)$ for the 25-50 $(>50)$ percent portfolios. Similar trends are observed for the earnings coefficients. The results here indicate the existence of a non-linear relationship between managerial ownership and the informativeness of earnings. As discussed in Section 3, the results suggest that higher levels of management ownership can result in sufficient voting power to guarantee future employment and increased earnings management in line with the entrenchment effect as indicated by Morck et al. (1988).

Table 2 provides descriptive statistics of selected variables used in the analysis. As shown in Table 2, companies with management ownership less than or equal to $25 \%$ are significantly larger than those whose management ownership is greater than $25 \% .^{6}$ The percentage of external unrelated block holdings for firms with management ownership less than or equal to $25 \%$ is also significantly higher than those whose management ownership is greater than $25 \%$. It is also interesting to note that the firms with greater than $25 \%$ management ownership have significantly higher discretionary accruals and income-increasing accruals. As 
Table 2

Descriptive Statistics

\begin{tabular}{|c|c|c|c|c|c|c|c|c|c|c|c|c|}
\hline \multirow[t]{2}{*}{ Variable } & \multicolumn{3}{|c|}{ Mean } & \multicolumn{2}{|c|}{ Standard Deviation } & \multicolumn{3}{|c|}{ Median } & \multicolumn{2}{|c|}{ First Quartile } & \multicolumn{2}{|c|}{ Third Quartile } \\
\hline & $\begin{array}{c}M G O W N \\
\leq 25 \%\end{array}$ & $\begin{array}{c}M G O W N \\
>25 \%\end{array}$ & Diff. & $\begin{array}{c}M G O W N \\
\leq 25 \%\end{array}$ & $\begin{array}{c}M G O W N \\
>25 \%\end{array}$ & $\begin{array}{c}M G O W N \\
\leq 25 \%\end{array}$ & $\begin{array}{c}M G O W N \\
>25 \%\end{array}$ & Diff. & $\begin{array}{c}M G O W N \\
\leq 25 \%\end{array}$ & $\begin{array}{c}M G O W N \\
>25 \%\end{array}$ & $\begin{array}{c}M G O W N \\
\leq 25 \%\end{array}$ & $\begin{array}{c}M G O W N \\
>25 \%\end{array}$ \\
\hline$R_{i t}$ & 0.265 & 0.157 & (a) & 0.426 & 0.447 & 0.217 & 0.044 & (a) & -0.008 & -0.128 & 0.465 & 0.306 \\
\hline$E_{i t} / P_{i t-1}$ & 0.129 & 0.074 & (a) & 0.223 & 0.216 & 0.078 & 0.050 & (a) & 0.031 & 0.003 & 0.169 & 0.116 \\
\hline $\operatorname{MGOWN}_{i}$ & 0.039 & 0.506 & (a) & 0.075 & 0.159 & 0.004 & 0.512 & (a) & 0.001 & 0.355 & 0.045 & 0.612 \\
\hline $\mathrm{BLOCK}_{i}$ & 0.517 & 0.153 & (a) & 0.219 & 0.185 & 0.525 & 0.089 & (a) & 0.378 & 0.000 & 0.697 & 0.224 \\
\hline $\mathrm{SIZE}_{i}$ & 11.937 & 11.257 & (a) & 2.260 & 1.730 & 12.089 & 11.063 & (a) & 10.576 & 10.283 & 13.496 & 12.163 \\
\hline $\mathrm{DEBT}_{i}$ & 0.413 & 0.454 & (c) & 0.252 & 0.258 & 0.350 & 0.258 & & 0.203 & 0.244 & 0.573 & 0.648 \\
\hline $\mathrm{RISK}_{i}$ & 1.197 & 1.192 & & 0.439 & 0.554 & 1.153 & 0.554 & & 0.955 & 0.793 & 1.502 & 1.614 \\
\hline $\mathrm{VAR}_{i}$ & 0.596 & 0.769 & (a) & 1.688 & 2.029 & 0.492 & 0.474 & & 0.267 & 0.239 & 1.083 & 0.866 \\
\hline GROWTH $_{i}$ & 1.281 & 1.140 & (a) & 0.539 & 0.460 & 1.116 & 1.011 & (a) & 0.967 & 0.877 & 1.216 & 1.272 \\
\hline $\mathrm{PERS}_{i}$ & 0.818 & 0.737 & (b) & 0.383 & 0.369 & 0.879 & 0.818 & & 0.562 & 0.566 & 0.879 & 0.969 \\
\hline $\mathrm{DAC}_{i t}$ & 0.033 & 0.027 & & 0.262 & 0.279 & 0.001 & 0.003 & & -0.044 & -0.063 & 0.068 & 0.074 \\
\hline$\left|\mathrm{DAC}_{i t}\right|$ & 0.101 & 0.179 & (a) & 0.213 & 0.271 & 0.046 & 0.063 & (b) & 0.016 & 0.016 & 0.111 & 0.182 \\
\hline DACINC $_{i t}$ & 0.121 & 0.213 & (b) & 0.274 & 0.308 & 0.054 & 0.063 & (c) & 0.020 & 0.019 & 0.112 & 0.256 \\
\hline
\end{tabular}

Notes:

$R_{i t}$ is the 12-months stock returns of firm $i$ in period $t$, starting nine months prior to fiscal year-end through three months after fiscal year-end. $E_{i t}$ is earnings per share of firm $i$ in period $t$ scaled by share price at beginning of period. $P_{i t}$ is share price for firm $i$ in period $t$. MGOWN $\mathrm{N}_{i}$ is the percentage of outstanding equity shares owned by directors. BLOCK $i$ is the percentage of external unrelated block holdings. SIZE $\mathrm{B}_{i}$ is the natural logarithm of market value of equity.

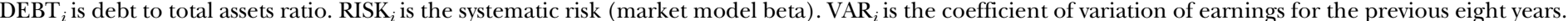
$\mathrm{GROWTH}_{i}$ is market to book ratio $\mathrm{PERS}_{i}$ is the persistence of earnings as measured by the first order autocorrelation in earnings for the previous eight years. $\mathrm{DAC}_{i t}$ is the amount of discretionary accruals. $\left|\mathrm{DAC}_{i t}\right|$ is the absolute amount of discretionary accruals. DACINC $i t$ is the amount of income-increasing discretionary accruals. The sample consists of 490 firm-year observations drawn from the 1990-1992 calendar years.

(a) : Significantly different at the $1 \%$ level (two-tailed).

(b) : Significantly different at the $5 \%$ level (two-tailed)

(c) : Significantly different at the $10 \%$ level (two-tailed). 
discussed in Section 2, the smaller firms have mainly developed from family businesses where the controlling owners are often the founders or their offspring. The significantly lower external unrelated block holdings for the group of firms with management ownership less than or equal to $25 \%$ provide stronger incentives for managers to manage earnings as evidenced by the significantly higher income-increasing discretionary accruals.

Table 3 presents the results of a pooled time-series crosssectional regression estimation of equation (2). Based on the findings in Table 1, the sample is divided into two sub-samples by management ownership and we regress the returns on earnings for each of the categories. Similar to prior research, the coefficient for $E_{i t} / P_{i t-1}$ for all the categories is positive and significant. However, the coefficient for $\operatorname{MGOWN}_{i} E_{i t} / P_{i t-1}$ is positive and significant for the management ownership category less than or equal to $25 \%$ and negative and significant for the category above $25 \%$. The coefficient for $\mathrm{BLOCK}_{i} E_{i t} / P_{i t-1}$ is positive and significant for all the management ownership categories. The above relations are not altered by the inclusion of the additional factors. ${ }^{7}$

These results indicate that there is a non-linear relation between the informativeness of earnings and managerial ownership. At low levels of management ownership, the informativeness of earnings increases with managerial ownership, in line with the predictions of agency theory and the findings reported by Warfield et al. (1995). However, at higher levels of managerial ownership, the informativeness of earnings decreases with management ownership. A possible reason for the contrary results include the entrenchment effect as indicated by Morck et al. (1988). The results on the relationship between external unrelated block holdings and the informativeness of earnings are consistent with the monitoring role of external unrelated block holdings which reduces opportunities for earnings management. The presence of pyramid holdings and minimal cross-holdings do not reduce the effects of monitoring by the external unrelated block holdings.

Morck et al. (1988) indicate entrenchment at 5\% to 25\% for US large firms, while McConnell and Servaes (1995) indicate incentive alignment between $0 \%$ and approximately $40-50 \%$ for 
Table 3

Regression of Returns on Earnings, Earnings-Management Ownership Interaction, Earnings-External Unrelated Block Holdings Interaction and Other Determinants of Earnings Explanatory Power

$$
\begin{aligned}
R_{i t}= & a_{0}+a_{1} E_{i t} / P_{i t-1}+a_{2} \operatorname{MGOWN}_{i} E_{i t} / P_{i t-1}+a_{3} \mathrm{BLOCK}_{i} E_{i t} / P_{i t-1}+a_{4} \mathrm{SIZE}_{i} E_{i t} / P_{i t-1}+a_{5} \mathrm{DEBT}_{i} E_{i t} / P_{i t-1}+a_{6} \mathrm{RISK}_{i} E_{i t} / P_{i t-1} \\
& +a_{7} \mathrm{VAR}_{i} E_{i t} / P_{i t-1}+a_{8} \mathrm{GROWTH}_{i} E_{i t} / P_{i t-1}+a_{9} \mathrm{PERS}_{i} E_{i t} / P_{i t-1}+u_{i t}
\end{aligned}
$$

\begin{tabular}{|c|c|c|c|c|c|c|c|c|c|c|c|c|}
\hline $\begin{array}{l}\text { Parameter } L \\
a_{O}\end{array}$ & $\begin{array}{l}\text { imates } \\
a_{1}\end{array}$ & $a_{2}$ & $a_{3}$ & $a_{4}$ & $a_{5}$ & $a_{6}$ & $a_{7}$ & $a_{8}$ & $a_{9}$ & $\begin{array}{c}\text { Sample } \\
\text { Size }\end{array}$ & $\begin{array}{l}A d j . \\
R^{2} \%\end{array}$ & $\begin{array}{c}\text { F-value } \\
\text { (Sig. } \\
\text { Level) }\end{array}$ \\
\hline \multicolumn{13}{|c|}{$0 \%<\mathrm{MGOWN}_{i} \leq 25 \%$} \\
\hline $\begin{array}{l}0.067 * * * \\
(4.126)\end{array}$ & $\begin{array}{l}0.799 * * * \\
(4.036)\end{array}$ & $\begin{array}{c}0.085^{*} \\
(1.867)\end{array}$ & $\begin{array}{l}0.351 * * \\
(2.612)\end{array}$ & $\begin{array}{c}-0.359 \\
(-2.554)\end{array}$ & $\begin{array}{c}-0.072 \\
(-1.133)\end{array}$ & $\begin{array}{c}-0.038 \\
(-0.475)\end{array}$ & $\begin{array}{c}-0.025 \\
(-0.765)\end{array}$ & $\begin{array}{c}0.000 \\
(0.005)\end{array}$ & $\begin{array}{l}0.156^{* *} \\
(2.181)\end{array}$ & 247 & 12.78 & $\begin{array}{l}12.794 \\
(0.000)\end{array}$ \\
\hline \multicolumn{13}{|c|}{ MGOWN $_{i}>25 \%$} \\
\hline $\begin{array}{l}0.138 * * * \\
(4.795)\end{array}$ & $\begin{array}{l}0.963 * * \\
(2.065)\end{array}$ & $\begin{array}{l}-0.410^{*} \\
(-1.813)\end{array}$ & $\begin{array}{l}0.364 * * * \\
(3.880)\end{array}$ & $\begin{array}{l}-0.389 * * \\
(-1.976)\end{array}$ & $\begin{array}{c}-0.235^{*} \\
(-1.679)\end{array}$ & $\begin{array}{c}-0.099 \\
(-0.531)\end{array}$ & $\begin{array}{c}0.036 \\
(0.570)\end{array}$ & $\begin{array}{c}0.030 \\
(0.174)\end{array}$ & $\begin{array}{c}0.054 \\
(0.436)\end{array}$ & 243 & 15.10 & $\begin{array}{c}13.256 \\
(0.000)\end{array}$ \\
\hline
\end{tabular}

Notes:

$R_{i t}$ is the 12-months stock returns of firm $i$ in period $t$, starting nine months prior to fiscal year-end through three months after fiscal year-end. $E_{i t}$ is earnings per share of firm $i$ in period $t . P_{i t}$ is share price for firm $i$ in period $t$. MGOWN ${ }_{i}$ is the percentage of outstanding equity shares owned by directors. BLOCK is

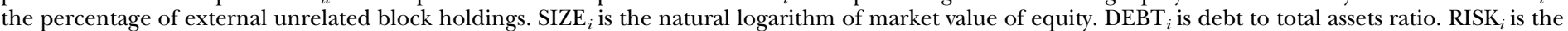
systematic risk (market model beta). $\mathrm{VAR}_{i}$ is the coefficient of variation of earnings for the previous eight years. GROWTH ${ }_{i}$ is market to book ratio $\mathrm{PERS}_{i}$ is the persistence of earnings as measured by the first order autocorrelation in earnings for the previous eight years. The sample consists of 490 firm-year observations drawn from the 1990-1992 calendar years. '***', '**' and '*' denote significance at the $1 \%, 5 \%$ and $10 \%$ levels respectively using a two-tailed test. 


\section{Table 4}

Regressions of Returns on Earnings, Earnings-Management Ownership Interaction, Earnings-External Unrelated Block Holdings Interaction and Other Determinants of Earnings Explanatory Power (Sub-classified by Years)

$$
\begin{aligned}
R_{i t}= & a_{0}+a_{1} E_{i t} / P_{i t-1}+a_{2} \operatorname{MGOWN}_{i} E_{i t} / P_{i t-1}+a_{3} \operatorname{BLOCK}_{i} E_{i t} / P_{i t-1}+a_{4} \operatorname{SIZE}_{i} E_{i t} / P_{i t-1}+a_{5} \mathrm{DEBT}_{i} E_{i t} / P_{i t-1}+a_{6} \mathrm{RISK}_{i} E_{i t} / P_{i t-1} \\
& +a_{7} \operatorname{VAR}_{i} E_{i t} / P_{i t-1}+a_{8} \operatorname{GROWTH}_{i} E_{i t} / P_{i t-1}+a_{9} \operatorname{PERS}_{i} E_{i t} / P_{i t-1}+u_{i t}
\end{aligned}
$$

\begin{tabular}{|c|c|c|c|c|c|c|c|c|c|c|c|c|}
\hline $\begin{array}{l}\text { Parameter } E \\
a_{O}\end{array}$ & $\begin{array}{c}\text { timates } \\
a_{1}\end{array}$ & $a_{2}$ & $a_{3}$ & $a_{4}$ & $a_{5}$ & $a_{6}$ & $a_{7}$ & $a_{8}$ & $a_{9}$ & $\begin{array}{l}\text { Sample } \\
\text { Size }\end{array}$ & $\begin{array}{l}A d j \\
R^{2} \%\end{array}$ & $\begin{array}{c}\text { F-value } \\
\text { (Sig. } \\
\text { Level) }\end{array}$ \\
\hline $\begin{array}{l}0.123 * * * \\
(4.502)\end{array}$ & $\begin{array}{c}0.599 * \\
(1.731)\end{array}$ & $\begin{array}{c}0.145^{*} \\
(1.829)\end{array}$ & $\begin{array}{c}0.420^{*} \\
(1.945)\end{array}$ & $\begin{array}{c}-0.152 \\
(-0.638)\end{array}$ & $\begin{array}{c}-0.096 \\
(-0.977)\end{array}$ & $\begin{array}{c}-0.073 \\
(-0.524)\end{array}$ & $\begin{array}{c}-0.004 \\
(-0.071)\end{array}$ & $\begin{array}{c}0.049 \\
(0.279)\end{array}$ & $\begin{array}{c}0.090 \\
(0.774)\end{array}$ & 90 & 7.75 & $\begin{array}{l}13.095 \\
(0.000)\end{array}$ \\
\hline \multicolumn{13}{|c|}{$1990-$ MGOWN $>25 \%$} \\
\hline \multicolumn{13}{|c|}{$1991-0 \%<\mathrm{MGOWN} \leq 25 \%$} \\
\hline $\begin{array}{c}0.025 \\
(0.781)\end{array}$ & $\begin{array}{c}0.706^{*} \\
(1.786)\end{array}$ & $\begin{array}{c}0.221 * \\
(1.816)\end{array}$ & $\begin{array}{c}0.422 * \\
(1.763)\end{array}$ & $\begin{array}{c}-0.276 \\
(-0.980)\end{array}$ & $\begin{array}{c}-0.055 \\
(-0.452)\end{array}$ & $\begin{array}{c}-0.061 \\
(-0.340)\end{array}$ & $\begin{array}{c}-0.048 \\
(-0.770)\end{array}$ & $\begin{array}{c}-0.051 \\
(-0.302)\end{array}$ & $\begin{array}{c}0.037 \\
(0.261)\end{array}$ & 87 & 6.90 & $\begin{array}{l}12.246 \\
(0.000)\end{array}$ \\
\hline
\end{tabular}


$1991-$ MGOWN $>25 \%$

$$
-0.078 * * * \quad 0.974 * \quad-0.576
$$

$\begin{array}{ll}(1.709) & (-1.412)\end{array}$

$\begin{array}{cc}0.363 * & -0.960 \\ (1.790) & (-1.430)\end{array}$

0.164

$0.190 \quad-0.078$

0.533

0.016

79

3.85

6.432

$(-3.713)$

$<\mathrm{MGOWN} \leq 25 \%$

$\begin{array}{ccc}1992-074^{* *} & 0.676^{*} & 0.142^{*}\end{array}$

(2.002)

(1.718)

(1.858)

$0.527 * \quad-0.345$

0.001

$-0.179$

0.007

$-0.016$

0.180

69

7.08

9.284

1992 - MGOWN > 25\%

\begin{tabular}{ccccccccccccc}
$0.119 * *$ & $0.984 *$ & -0.546 & $0.319^{*}$ & -0.366 & -0.084 & -0.359 & -0.035 & 0.389 & -0.021 & 93 & 4.60 & 7.746 \\
$(2.174)$ & $(1.769)$ & $(-1.637)$ & $(1.809)$ & $(-0.673)$ & $(-0.213)$ & $(-0.834)$ & $(-0.321)$ & $(0.826)$ & $(-0.051)$ & & $(0.000)$ \\
\hline
\end{tabular}

Notes:

$R_{i t}$ is the 12-months stock returns of firm $i$ in period $t$, starting nine months prior to fiscal year-end through three months after fiscal year-end. $E_{i t}$ is earnings per share of firm $i$ in period $t . P_{i t}$ is share price for firm $i$ in period $t . \mathrm{MGOWN}_{i}$ is the percentage of outstanding equity shares owned by directors. BLOCK $i$ is the percentage of external unrelated block holdings. $\mathrm{SIZE}_{i}$ is the natural logarithm of market value of equity. $\mathrm{DEBT}_{i}$ is debt to total assets ratio. RISK $\mathrm{R}_{i}$ is the systematic risk (market model beta). $\mathrm{VAR}_{i}$ is the coefficient of variation of earnings for the previous eight years. GROWTH ${ }_{i}$ is market to book ratio $\mathrm{PERS}_{i}$ is the persistence of earnings as measured by the first order autocorrelation in earnings for the previous eight years. The sample consists of 490 firm-year observations drawn from the 1990-1992 calendar years. ' $* * *$ ', '**' and '*' denote significance at the 1\%, 5\% and 10\% levels respectively using a two-tailed test. 
a larger sample of US large and small firms. Kole (1995) suggests that the different findings of Morck et al. and McConnell and Servaes are attributable to differences in the size of the firms analyzed. The 25\% entrenchment level for Singapore firms can be attributed to the following reason. As shown in Table 2, companies with below $25 \%$ management ownership have significantly higher external unrelated block holdings (mean(median) of $51.7 \%(52.5 \%)$ ) than those with management ownership greater than $25 \%$ (mean(median) of $15.3 \%(8.9 \%)$ ). About half of the below $25 \%$ group of companies have significant government or state holdings. The significantly higher block holdings for the below $25 \%$ group implies stronger monitoring and as such less opportunities for entrenchment to take place. Entrenchment therefore occurs at higher levels of ownership where the presence of block holder monitoring is less effective.

To test the robustness of the results, further tests were conducted by sub-classifying the sample by years and estimating equation (1). Similar results are obtained for the sub-samples. That is, the coefficient for $E_{i t} / P_{i t-1}$ is positive and significant in all categories, the coefficient for $\mathrm{MGOWN}_{i} E_{i t} / P_{i t-1}$ is positive and significant for the management ownership category less than or equal to $25 \%$ and negative (or negative and significant) for the category above $25 \%$. The coefficient for $\operatorname{BLOCK}_{i} E_{i t} / P_{i t-1}$ is positive and significant for all the management ownership categories.

The second part of the analysis investigates the relation between management ownership and external unrelated block holdings with income-increasing discretionary accruals (equation (3)). We divide the sample into two ownership categories, in line with the results obtained above. Table 5 presents the results. For both categories, the relation between external unrelated block holdings and income-increasing discretionary accruals is negative and significant. The results suggest the monitoring role of high external unrelated block holdings and lesser opportunities for earnings management. These results are similar to those by Rajgopal et al. (1999) which provides evidence of a negative relation between institutional ownership and the absolute value of discretionary accruals.

The relation between management ownership and incomeincreasing discretionary accruals is negative and significant for 
Table 5

Regression of Income-Increasing Discretionary Accruals on Management Ownership, External Unrelated Block Holdings and Other Determinants of Income-Increasing Discretionary Accruals

DACINC $_{i t}=b_{0}+b_{1} \mathrm{MGOWN}_{i}+b_{2} \mathrm{BLOCK}_{i}+b_{3} \mathrm{SIZE}_{i}+b_{4} \mathrm{DEBT}_{i}+b_{5} \mathrm{RISK}_{i}+b_{6} \mathrm{VAR}_{i}+b_{7} \mathrm{GROWTH}_{i}+b_{8} \mathrm{PERS}_{i}+u_{i t}$

\begin{tabular}{|c|c|c|c|c|c|c|c|c|c|c|}
\hline $\begin{array}{l}\text { Parameter Estimates } \\
b_{0} \quad b_{1}\end{array}$ & $b_{2}$ & $b_{3}$ & $b_{4}$ & $b_{5}$ & $b_{6}$ & $b_{7}$ & $b_{8}$ & $\begin{array}{l}\text { Sample } \\
\text { Size }\end{array}$ & $\begin{array}{l}A d j \\
R^{2} \%\end{array}$ & $\begin{array}{c}\text { F-value } \\
\text { (Sig. Level) }\end{array}$ \\
\hline $\begin{array}{cc}0 \%<\mathrm{MGOWN}_{i} \leq 25 \% \\
0.519^{* * *} \quad-0.273^{* * * *} \\
(3.124) & (-2.725)\end{array}$ & $\begin{array}{l}-0.355^{* * *} \\
(-3.576)\end{array}$ & $\begin{array}{l}-0.159 \\
(-1.625)\end{array}$ & $\begin{array}{c}0.004 \\
(0.042)\end{array}$ & $\begin{array}{c}0.013 \\
(0.144)\end{array}$ & $\begin{array}{c}0.006 \\
(0.071)\end{array}$ & $\begin{array}{c}0.022 \\
(0.237)\end{array}$ & $\begin{array}{c}0.078 \\
(0.844)\end{array}$ & 158 & 11.9 & $\begin{array}{c}2.855 \\
(0.001)\end{array}$ \\
\hline $\begin{array}{cc}\text { MGOWN }_{i}> & 25 \% \\
0.145 & 0.203 * * * \\
(0.603) & (2.259)\end{array}$ & $\begin{array}{l}-0.621 * * * \\
(-3.974)\end{array}$ & $\begin{array}{c}0.037 \\
(0.441)\end{array}$ & $\begin{array}{l}-0.044 \\
(-0.522)\end{array}$ & $\begin{array}{c}0.189 * \\
(1.964)\end{array}$ & $\begin{array}{c}0.025 \\
(0.308)\end{array}$ & $\begin{array}{c}0.133 \\
(1.605)\end{array}$ & $\begin{array}{c}0.082 \\
(0.881)\end{array}$ & 156 & 17.7 & $\begin{array}{c}4.406 \\
(0.000)\end{array}$ \\
\hline
\end{tabular}

Notes:

$\mathrm{DACINC}_{i t}$ is the income-increasing discretionary accruals. $\mathrm{MGOWN}_{i}$ is the percentage of outstanding equity shares owned by directors. BLOCK ${ }_{i}$ is the percentage of external unrelated block holdings. $\mathrm{SIZE}_{i}$ is the natural logarithm of market value of equity. DEBT ${ }_{i}$ is debt to total assets ratio. RISK is $_{i}$ the systematic risk (market model beta). $\mathrm{VAR}_{i}$ is the coefficient of variation of earnings for the previous eight years. $\mathrm{GROWTH}_{i}$ is market to book ratio PERS $_{i}$ is the persistence of earnings as measured by the first order autocorrelation in earnings for the previous eight years. The sample consists of 490 firm-year observations drawn from the 1990-1992 calendar years. '***', '**' and '*' denote significance at the 1\%, $5 \%$ and $10 \%$ levels respectively using a two-tailed test. 
Table 6

Regressions of Income-Increasing Discretionary Accruals on Management Ownership, External Unrelated Block Holdings and Other Determinants of Income-Increasing Discretionary Accruals (Sub-classified by Years)

$\mathrm{DACINC}_{i t}=b_{0}+b_{1} \mathrm{MGOWN}_{i}+b_{2} \mathrm{BLOCK}_{i}+b_{3} \mathrm{SIZE}_{i}+b_{4} \mathrm{DEBT}_{i}+b_{5} \mathrm{RISK}_{i}+b_{6} \mathrm{VAR}_{i}+b_{7} \mathrm{GROWTH}_{I}+b_{8} \mathrm{PERS}_{i}+u_{i t}$

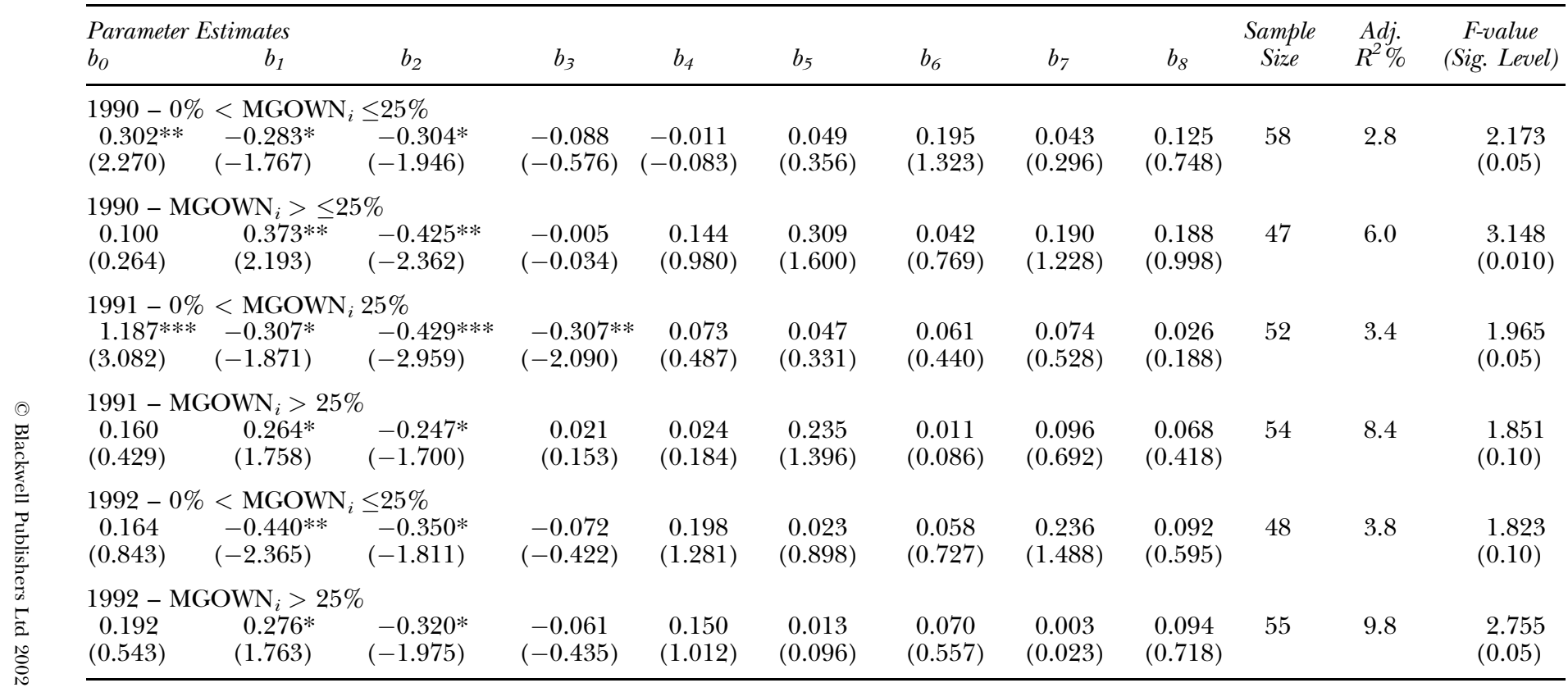




\section{Table 6 (Continued)}

Notes:

DACINC $_{i t}$ is the income-increasing discretionary accruals. MGOWN ${ }_{i}$ is the percentage of outstanding equity shares owned by directors. BLOCK ${ }_{i}$ is the percentage of external unrelated block holdings. $\mathrm{SIZE}_{i}$ is the natural logarithm of market value of equity. DEBT is debt to total assets ratio. $\mathrm{RISK}_{i}$ is the systematic risk (market model beta). $\mathrm{VAR}_{i}$ is the coefficient of variation of earnings for the previous eight years. $\mathrm{GROWTH}_{i}$ is market to book ratio. PERS $i$ is the persistence of earnings as measured by the first order autocorrelation in earnings for the previous eight years. The sample consists of 490 firm-year observations drawn from the 1990-1992 calendar years. '***', '**' and '*' denote significance at the $1 \%, 5 \%$ and $10 \%$ levels respectively using a two-tailed test.

the management ownership category less than or equal to $25 \%$, but positive and significant for the category above 25\%. These findings suggest the non-linear relation between incomeincreasing discretionary accruals and managerial ownership and are consistent with the above analysis on the informativeness of earnings. When management ownership is less than or equal to $25 \%$, the agency theory predictions hold and earnings management is reduced as managerial ownership increases. However, as management ownership increases to beyond $25 \%$, the entrenchment effect sets in and aggressive earnings management through income-increasing discretionary accruals exists. The analysis is repeated using absolute discretionary accruals and qualitatively similar results are obtained.

Similar results are obtained by sub-classifying the sample by years and estimating the relation between income-increasing discretionary accruals and managerial ownership and external unrelated block holdings. The results are shown in Table 6 .

\section{CONCLUSION}

The purpose of this study is to further extend previous studies by empirically examining how managerial ownership and external unrelated block holdings affect the informativeness of earnings. The results are in contrast to previous studies. There exists a nonlinear relation between managerial ownership and the informativeness of earnings. At low levels of management ownership, the informativeness of earnings increases with managerial ownership. However, at higher levels of managerial ownership, the entrenchment effect sets in and high managerial 
ownership becomes ineffective in aligning managers to take value-maximizing actions. The evidence also shows a strong positive relationship between external unrelated block holdings and the informativeness of earnings. This is consistent with the role of a large shareholder acting as monitor, which suggests less opportunity for earnings management. The presence of pyramid holdings and minimal cross-holdings do not reduce the effects of monitoring by the external unrelated block holdings. These results are supported when income-increasing discretionary accruals are used to measure the extent of earnings management and its effects on the informativeness of earnings.

\section{NOTES}

1 Other prior studies include Dempsey, Hunt and Schroeder (1993) which shows that the propensity to report extraordinary items in a favourable manner is significantly greater for non-owner managers than for owner managers; Beattie et al. (1994) which shows that income smoothing through extraordinary items is negatively associated with external unrelated ownership concentration; and Carlson and Bathala (1997) which provides findings that the lower the proportion of inside ownership the higher the probability of a firm being an income smoother.

2 In Singapore, a corporation is deemed to be a subsidiary of another corporation if that other corporation either controls the composition of the board of directors of the first-mentioned corporation; or controls more than half of the voting power of the first-mentioned corporation; or holds more than half of the issued share capital of the first-mentioned corporation (excluding any part thereof which consists of preference shares).

3 Using Australian data, Gul and Lyn (1998) show that the association between stock returns and earnings is not significantly stronger for high management ownership firms when these firms have high levels of debt. They also show that the informativeness of earnings for firms with low management ownership is higher for firms audited by the Big 6 than for non-Big 6 auditors. This issue is not of concern to us since more than $90 \%$ of the firms listed on the Stock Exchange of Singapore are audited by Big 6 auditors.

4 CAR, cumulative abnormal returns are also used for a similar period as an alternative specification for returns.

5 These percentages are representative of the industry classification of the population of firms listed on the Stock Exchange of Singapore.

$625 \%$ is used based on the results shown in Table 1 where the non-linear relationship occurs.

7 Qualitatively similar results are obtained using CAR as an alternative specification for returns. 


\section{REFERENCES}

Beattie, V., S. Brown, D. Ewers, B. John, S. Manson, D. Thomas and M. Turner (1994), 'Extraordinary Items and Income Smoothing: A Positive Accounting Approach', Journal of Business Finance Eं Accounting, Vol. 21, No. 6 (September), pp. 791-811.

Becht M. and A. Roell (1999), 'Block Holdings in Europe: An International Comparison', European Economic Review, Vol. 43, No. 4-6, pp. 1049-56.

Carlson, S.J. and C. T. Bathala (1997), 'Ownership Differences and Firms' Income Smoothing Behavior', Journal of Business Finance E Accounting, Vol. 24, No. 2 (March). pp. 179-96.

Claessens, S., S. Djankov and L. Lang (2000), 'The Separation of Ownership and Control in East Asian Corporations', Journal of Financial Economics, Vol. 58, pp. 81-112.

Dechow, P., R.G. Sloan and A.P. Sweeney (1995), 'Detecting Earnings Management', The Accounting Review, Vol. 70, No. 2, pp. 193-225.

(1996), 'Causes and Consequences of Earnings Manipulation: An Analysis of Firms Subject to Enforcement Actions by the SEC', Contemporary Accounting Research, Vol. 13, No. 1 (Spring), pp. 1-36.

Dempsey, S.J., H.G. Hunt III and N. W. Schroeder (1993), 'Earnings Management and Corporate Ownership Structure: An Examination of Extraordinary Item Reporting', Journal of Business Finance $\mathcal{E}$ Accounting, Vol. 20, No. 4 (June), pp. 479-500.

Denis, D. and J. Serrano (1996), 'Active Investors and Management Turnover Following Unsuccessful Control Contests', Journal of Financial Economics, Vol. 40, pp. 239-66.

Jensen, M.C. and W.H. Meckling (1976), 'Theory of the Firm: Managerial Behavior, Agency Costs and Ownership Structure', Journal of Financial Economics, Vol. 3, pp. 305-60.

Jones, J.J. (1991), 'Earnings Management During Import Relief Investigations', Journal of Accounting Research, Vol. 29, pp. 193-228.

Kang, J.K. and A. Shivdasani (1995), 'Firm Performance, Corporate Governance and Top Executive Turnover in Japan', Journal of Financial Economics, Vol. 38 , pp. 29-58.

Kaplan, S. and B. Minton (1994), 'Appointments of Outsiders to Japanese Boards: Determinants and Implications for Managers', Journal of Financial Economics, Vol. 36, pp. 225-57.

Kole, S.R. (1995), 'Measuring Managerial Equity Ownership: A Comparison of Sources of Ownership Data', Journal of Corporate Finance, Vol. 1, pp. 413-35.

La Porta, R., F. Lopez-de-Silanes and A. Shleifer (1999), 'Corporate Ownership Around the World', Journal of Finance, Vol. 54, No. 2, pp. 471-517.

McConnell, J.J. and H. Servaes (1990), 'Additional Evidence on Equity Ownership and Corporate Value', Journal of Financial Economics, Vol. 27, pp. 595-612.

Morck, R., A. Shleifer and R. Vishny (1988), 'Management Ownership and Market Valuation: An Empirical Analysis', Journal of Financial Economics, Vol. 20, pp. 293-315.

Rajgopal, S., M. Venkatachalam and J. Jiambalvo (1999), 'Is Institutional Ownership Associated with Earnings Management and the Extent to which Stock Prices Reflect Future Earnings?' Working Paper (University of Washington).

Shleifer A. and R.W. Vishny (1986), 'Large Shareholders and Corporate 
Control', Journal of Political Economy, Vol. 94, pp. 461-88.

Teets and Wasley (1996), 'Estimating Earnings Response Coefficients: Pooled versus Firm-specific Models', Journal of Accounting and Economics, Vol. 21, pp. 279-95.

Teoh, S. and T.J. Wong (1998), 'Earnings Management and the Underperformance of Seasoned Equity Offerings', Journal of Financial Economics, Vol. 50, pp. 63-100.

Warfield, T.D., J.J. Wild and K.L. Wild (1995), 'Managerial Ownership, Accounting Choices, and Informativeness of Earnings', Journal of Accounting and Economics, Vol. 20, pp. 61-91. 